\title{
Socio-economic impacts of the adoption of MIS (Micro-irrigation system) among small and marginal farmers of Coimbatore district, India
}

\author{
S. Kiruthika* \\ Department of Agricultural Economics, Tamil Nadu Agricultural University, Coimbatore-641003 \\ (Tamil Nadu), India
}

\section{Suresh Kumar}

Department of Agricultural Economics, Tamil Nadu Agricultural University, Coimbatore-641003 (Tamil Nadu), India

*Corresponding author. Email: s.malarvizhi1996@gmail.com

\section{Article Info}

https://doi.org/10.31018/ jans.v12i3.2312

Received: July 3, 2020

Revised: July 28, 2020

Accepted: August 6, 2020

\section{How to Cite}

Kiruthika, S. and Kumar, D. S. (2020). Socio-economic impacts of the adoption of MIS (Micro-irrigation system) among small and marginal farmers of Coimbatore district, India.. Journal of Applied and Natural Science, 12(3): 312 - 318. https://doi.org/10.31018/jans.v12i3.2312

\begin{abstract}
Considerable attention has been given to micro-irrigation technologies by policymakers to help farmers in overcoming water scarcity problems. In this paper, the potential impacts of MIS on farmers' livelihood and economic viability of using drip in banana cultivation were analyzed using discounted cash flow techniques. The study focused on small and marginal farmers of Coimbatore district of Tamil Nadu as they were provided with $100 \%$ subsidy. Adoption of MIS increased the total cropped area (6.54\%), extended area under irrigation (6.55\%), increased cropping intensity $(69.19 \%)$ and irrigation intensity $(70.95 \%)$. Investment on drip irrigation system by farmers were found financially feasible (NPV Rs.43,851.16, BCR 1.42 and IRR $30.88 \%$ ). The study also brought out the constraints faced by farmers in the adoption of MIS such as lack of technical support, the inefficiency of the system with poor quality water and damage caused by animals. The research work would be helpful in understanding the advantages of using MIS by small and marginal farmers and problems encountered by them in adoption even though the investment was economically viable.
\end{abstract}

Keywords: Adoption, Economics, Micro irrigation systems, Small and marginal farmers

\section{INTRODUCTION}

Water, a significant input of agriculture, is becoming a scarce resource and limiting the development of agricultural households. India is the largest user of groundwater in the world using 260cubic km per year, i.e. $25 \%$ of all groundwater extracted globally, ahead of China and the USA. Out of the total net annual groundwater availability, $90 \%$ is used in irrigation while the rest $10 \%$ used for the domestic and industrial purpose (Government of India, 2019). The net irrigated area in India increased from 12.46 Mha in 1960-1961 to $26.50 \mathrm{Mha}$ in 2014-2015. The net area irrigated under groundwater increased from $32.6 \%$ of net irrigated area in 1960 to $62.82 \%$ in 2015 (Government of India, 2018). This indicates the increasing demand for water in agriculture which can be met by increasing the irrigation efficiency at farm level.

An effective way to increase water use efficiency in agriculture is adopting micro-irrigation technologies like drip and sprinkler irrigation. In the drip method of irrigation, water losses occurring through evaporation and distribution are completely absent as it delivers water directly to the root zone of the crop (INCID, 1994: Narayanamoorthy, 1996). The other benefits of using MIS were increased water use efficiency $(50 \%$ to $90 \%$ ) due to reduction in conveyance losses, reduced energy utilization $(30.50 \%)$ and saves fertilizer consumption by $28.50 \%$, increased productivity of crops and fruits by $42.40 \%$ and $52.70 \%$ respectively (IAI et al., 2016). The productivity of green chillies increased by $52.45 \%$ with drip irrigation, where the cost of cultivation was reduced by $29.14 \%$ and net profit increased by $142.15 \%$ (Narayanamoorthy et al., 2016). Sprinkler method of irrigation significantly improved crop yield (21\%), water productivity (34\%), increased technical efficiency $(20 \%)$ and saved water use (15\%) and energy utilization (8\%) in Bundelkhand 
region of Uttar Pradesh (Kishore, 2019).

In India, the major crops under drip irrigation are cotton, sugarcane, banana, grapes, pomegranate, coconut and vegetables like cabbage, cauliflower, chilli, ladies finger and brinjal (Kumar, 2016). Sprinkler method of irrigation is used for field crops like sorghum, pearl millet, groundnut and mustard (Kumar, 2016). MIS is viable for horticultural crops and orchards as even a marginal increase in yield results in a significant rise in crop value for high valued crops (Dhawan, 2000 ). About 50 per cent saving in water and 20 to 30 per cent yield increase in coconut was seen in Coimbatore district of Tamil Nadu after using drip (Palanichamy et al., 2002). Discounted flow techniques were used to study the economic viability of growing capsicum in West Bengal, and the net present worth was found to be Rs. 3,09,734.90 (Singh, 2008). Using drip irrigation system in capsicum resulted in increased yield by $57 \%$ and net income by $54 \%$ and benefit-cost ratio was found to be 2.44 in drip irrigation system against 2.01 for conventional irrigation (Paul et al., 2013). In Karnataka, net return per acre for crops under drip irrigation was found to be higher than conventional irrigation where it was Rs.26,208 for tomato, Rs.7,621 for mulberry and Rs.52,084 for grapes (Chandrakanth et al., 2013).

Vaibhav and Makwana (2017), conducted impact analysis in terms of water saving, fertilizer and pesticide usage and yield increase in Kodinar region of Gujarat. Maximum water saving was found to be in sugarcane $\left(6195 \mathrm{~m}^{3} / \mathrm{ha}\right)$. A study by Kumar et al., (2004) conducted a benefit-cost analysis of using drip irrigation which resulted that the incremental net returns were higher for cash crops like cotton, groundnut and banana than food crops like bajra and wheat. A study by Sivanappan (1994) on the socio-economic benefit of drip in Tamil Nadu concluded that the Benefit Cost (BC) ratio ranged from 1.3 for sugarcane to 11.5 for grapes and the $B C$ ratio improved when the benefits of watersaving were reckoned with.

A significant difference in cost of cultivation was observed between drip adopters and farmers using the surface method of irrigation across four districts of $\mathrm{Gu}$ jarat. The major advantages of MIS over the conventional method were higher yield, higher profit, rise in labour productivity and reduction in the unit cost of production (Shiyani et al., 1999). Analysis on the economic performance of drip among coconut cultivators of Coimbatore (Palanichamy et al., 2002) showed that the additional cost of drip was Rs.31,165/ha and cost of cultivation went up by 19 per cent with drip irrigation. The financial viability of drip irrigation indicated more than 30 per cent modified internal rate of return in the water scarcity condition. The reasons for improved financial viability were the higher price of coconut, 20 to 30 per cent increase in yield, increased fertilizer use efficiency, reduction in expenditure on plant protection chemicals and labour saving at a rate of Rs.3000/ha. Shashidhara et al. (2007) carried out a study on drip irrigation in banana and areca nut in Shimoga and Davanagere districts of Karnataka. About $70 \%$ of farmers expressed the improved quality of the produce and drip irrigation increase returns of the farmers by $5.92 \%$ and $3.54 \%$ in banana and areca nut, respectively. Suresh Kumar and Palanisami (2014) studied the impacts of drip irrigation on farming systems and concluded that it had significant effect on resources saving, cost of cultivation, crop yield and farm profitability and suggested the promotion of drip irrigation in water scarce regions.

Pradhan Mantri Krishi Sinchayee Yojna (PMKSY) was launched in 2015, integrating micro-irrigation in the flagship scheme as an integral component. The area under Micro Irrigation in Tamil Nadu is 0.5 mha in which $82 \%$ ( $0.41 \mathrm{mha})$ of the area is under drip irrigation and $18 \%$ ( 0.09 mha) of the area is covered by sprinkler. To reduce the financial burden of farmers, the state government of Tamil Nadu provides 100 per cent subsidy to small and marginal farmers and 75 per cent to others. More specifically the paper aims to (i) study the impact of MIS on socio-economic aspects of small and marginal farmers (ii) examine the economic viability of using MIS like drip irrigation system among small and marginal farmers (iii) understand the constraints faced by farmers in adoption of the technology.

\section{MATERIALS AND METHODS}

Study area: The study was conducted in Coimbatore district of Tamil Nadu between December 2019 and February 2020. The area was selected as it had the highest area under MIS in 2018-2019. The data for this study was obtained from the primary survey of 120 farmers by the multi-stage random sampling procedure. Two blocks were selected in the district from which two villages of each block were selected at random. About 30 small and marginal farmers were selected at random from each village for primary survey including adopters of MIS, farmers using conventional irrigation methods and farmers who discontinued using MIS. A total of 120 farmers were selected, among which 70 farmers were adopters of MIS.

In order to accomplish the objectives of the study, necessary primary data was obtained from the sample respondents by means of personal interviews, using a pre-tested and structured interview schedule. The data included general information of the respondents such as age, educational level, family size, landholding pattern, source of irrigation, cropping pattern and animal husbandry. Comprehensive data was collected on type and components of MIS used, years of usage, cost of 
installation and cost of cultivation with and without using MIS and advantages and disadvantages of the system.

Methodology: The approach suggested by the Cost of Cultivation for Principal Crops was used to estimate the cost of cultivation of banana using micro-irrigation technologies and the cost of cultivation of banana without using MIS. The total cost was classified as fixed costs and variable costs. Fixed costs include land revenue, depreciation of farm buildings, tools and implements and rental value of owned land. The variable cost includes cost on ploughing, seeds, manures and fertilizers, after cultivation practices, plant protection chemicals, human labour and interest on working capital. Interest on working capital was calculated at the rate which banks were advancing short-term loans. The prime lending rate during the agriculture year was 12.00 per cent for crop loan.

Net present value (NPV): NPV allows the estimation of economic costs and benefits attributable to different farming practices. It is given by,

$$
N P V=\sum_{t=1}^{n} \frac{B_{t}-c_{t}}{(1+r)^{t}}
$$

Where,

$B_{t}=$ benefit or revenue earned in the year $t$

$\mathrm{C}_{\mathrm{t}}=$ Costs incurred in the year $\mathrm{t}$

$r=$ Discount rate

$t=$ years of life period $1,2, \ldots . n$

Benefit cost ratio: Benefit Cost Ratio (BCR) refers to the ratio of discounted net cash flows to investments. Cost Benefit analysis evaluates and compares all costs and benefits of adoption process. The ratio must be more than 1 for an enterprise to be considered worthwhile. The formula for calculating Benefit Cost Ratio (BCR) is given below

$$
\text { B: C Ratio }=\frac{\sum_{t=1}^{n}\left[\frac{B_{t}}{\left[(1+r) t^{t^{2}}\right.}\right]}{\sum_{t=1}^{n}\left[\frac{L_{t}}{(1+r)^{t}}\right]}
$$

Internal rate of return (IRR): The rate of discount at which the net present Value of the project is zero is the Internal Rate of Return (IRR) of the project. The net cash inflows were discounted to determine the present worth of the investment.

$$
\sum_{t=1}^{n} \frac{\left(B_{t}-C_{t}\right)}{(1+r)^{t}}=0
$$

The method of interpolation is given as

$$
\text { IRR = Lower discount } \begin{aligned}
& \text { rate } \\
& \text { refference between } \\
& \text { the two two discount } \\
& \text { rates }
\end{aligned}\left(\begin{array}{l}
\begin{array}{l}
\text { Present worth of cash flows } \\
\text { at lower discount rate }
\end{array} \\
\begin{array}{l}
\text { absolute difference between } \\
\text { present worth of cash flows } \\
\text { stream at the two discount } \\
\text { rate }
\end{array}
\end{array}\right)
$$

Adoption of MIS involves fixed capital, and thus, it is essential to take into account the income and cost stream for the whole life span of drip investment. But it is difficult to uncover the actual cash flows for the entire life span of drip investment because of the absence of observed temporal information on benefits and costs. Hence, few rational assumptions are made to estimate both cash inflows and cash outflows for drip investment.

- The life period of the drip system is assumed to be seven years.

- The cost of cultivation and income generated using drip irrigation method is assumed to be constant during the entire life period of drip.

- The cultivation technology of banana crop is assumed to remain constant during the entire life period of the drip system.

\section{RESULTS AND DISCUSSION}

General characteristics of farmers: The results of the study on changes in landholding pattern, cropped area, irrigated area and other cropping characteristics of adopters and non-adopters of the technology are given in table 1. The gross cropped area and gross irrigated area calculated for all crops cultivated by the sample farmers indicated that the farm size increased from 1.45 ha to 1.49 ha after adopting MIS while it was only 1.25 ha for non-adopters. The gross cropped area also increased by 3.35 per cent after using MI technologies and the cropping intensity also increased by 2.16 per cent implying that water saved was used for additional area brought under cultivation and for next season crops.

Gross area under irrigation increased by 6.54 per cent and irrigation intensity increased by 3.69 per cent as micro-irrigation technologies enabled farmers to save water and extend the area under irrigation. Failure of monsoon and failure of open wells lead to usage of drip or sprinkler irrigation for efficient usage of water which is seen by the decrease in the percentage of area irrigated by wells and increase in area irrigated with tubewells. Percentage of the area under rainfed condition was higher $(23.76 \%)$ for non-adopters as they don't have adequate water for cultivating crops under the irrigated condition and were highly dependent on rainfall.

Impacts of micro-irrigation technologies on cropping pattern: The changes in the cropping pattern of farmers after adopting MIS are given in table 2 . It is evident from the results that area under banana was the highest for adopters and lowest for cotton as MIS is convenient for wider spaced horticultural crops. The area under cereals, sugarcane, turmeric, cotton and pulses decreased after the adoption of MIS while the area under the banana, areca nut, coconut and vegetables increased. It gives a clear picture of significant change (at $5 \%$ level) in cropping pattern by farmers adopting $\mathrm{Ml}$ technologies. 
Kiruthika, S. and Kumar, D. S. / J. Appl. \& Nat. Sci. 12(3): 312 - 318 (2020)

Table 1. Changes in the cropped area and irrigation conditions of small and marginal farmers of Coimbatore district.

\begin{tabular}{|c|c|c|c|c|}
\hline \multirow{2}{*}{ S.No. } & \multirow{2}{*}{ Particulars } & \multicolumn{2}{|c|}{ Adopters (Hectares) } & \multirow{2}{*}{$\begin{array}{l}\text { Non-adopters } \\
\text { (Hectares) }\end{array}$} \\
\hline & & Before using MIS & After using MIS & \\
\hline 1 & Farm size & 1.45 & 1.49 & 1.25 \\
\hline 2 & Net sown area & 1.20 & 1.28 & 1.06 \\
\hline 3 & Gross cropped area & 1.79 & 1.85 & 1.59 \\
\hline 4 & Cropping intensity (\%) & 67.03 & 69.19 & 66.67 \\
\hline 5 & Net irrigated area & 1.13 & 1.27 & 0.80 \\
\hline 6 & Gross irrigated area & 1.68 & 1.79 & 1.29 \\
\hline 7 & Irrigation intensity (\%) & 67.26 & 70.95 & 62.02 \\
\hline 8 & $\begin{array}{l}\text { Percentage of area irrigated by } \\
\text { wells to total cropped area }\end{array}$ & 6.38 & 2.53 & 2.10 \\
\hline 9 & $\begin{array}{l}\text { percentage of area irrigated with } \\
\text { tubewells to total cropped area }\end{array}$ & 85.51 & 88.53 & 58.53 \\
\hline 10 & $\begin{array}{l}\text { Percentage of area irrigated with } \\
\text { MIS to total irrigated area }\end{array}$ & - & 82.86 & - \\
\hline 11 & $\begin{array}{l}\text { Percentage of area under rainfed } \\
\text { condition }\end{array}$ & 5.35 & 1.53 & 23.76 \\
\hline
\end{tabular}

Table 2. Change in cropping pattern of small and marginal farmers of Coimbatore district.

\begin{tabular}{clccc}
\hline S.No. & Crops & Before adopting MIS & After adopting MIS & Non-adopters \\
\hline 1 & Cereals & $8.80(7.03)$ & $2.60(2.01)$ & $1.80(3.14)$ \\
2 & Banana & $24.00(19.18)$ & $29.10(22.50)$ & $6.00(10.45)$ \\
3 & Sugarcane & $11.00(9.79)$ & $1.40(1.08)$ & $1.60(2.79)$ \\
4 & Cotton & $2.00(1.60)$ & $0.80(0.62)$ & $6.10(10.63)$ \\
5 & Turmeric & $16.00(12.79)$ & $7.60(5.88)$ & $0.40(0.70)$ \\
6 & Arecanut & $10.50(8.39)$ & $14.10(10.90)$ & $2.70(4.70)$ \\
7 & Coconut & $24.54(19.61)$ & $27.54(21.30)$ & $1.70(2.96)$ \\
8 & Vegetables & $22.10(17.66)$ & $28.32(21.90)$ & $10.10(17.60)$ \\
9 & pulses & $3.80(3.04)$ & $2.00(1.55)$ & $1.10(5.09)$ \\
10 & Fodder crops & $6.10(4.87)$ & $7.28(5.63)$ & $15.60(27.18)$ \\
\hline
\end{tabular}

Note: figures in parenthesis indicate percentage to gross cropped area

The area under banana is the highest among adopters followed by vegetables and coconut while the least area with MIS is under cotton. The area under fodder crops is the highest among non-adopters, while the area under turmeric is the lowest. Other major crops cultivated by non-adopters are cotton, banana and vegetables that explains the pre-determined cropping pattern of farmers using the conventional method of irrigation. They are reluctant to move towards wider spaced horticultural crops by adopting MIS.

Economics of MIS: Among the crops cultivated using drip irrigation by sample farmers banana covers the largest share to gross cropped area $(22.50 \%)$. Thus the financial viability of the technology on banana cultivation was analyzed using discounted cash flow techniques. It is assumed that the average life period of the drip irrigation system was 7 years for banana and the farmers follow the same cultivation practices for all the seven years considered. An interest rate of 12 per cent was used in the study.

As given in table 3 , the annual cost of the drip irrigation system was Rs.1,00,225/ha in which 92.55 per cent is attributed to fixed cost and 7.45percent is working cost. There is no electricity charges as power supply for farmers is free of cost in Tamil Nadu.

As seen in Table 4, the average yield of banana was $21.35 \mathrm{t} /$ ha under drip irrigation that was higher by 6.48 per cent compared with flood irrigation which resulted in increased net returns by 38.23 per cent. The net returns under drip irrigation were Rs.3,44,888/ha while it was Rs. 2,49,511/ha in flood irrigation. The cost of cultivation of banana under drip technology was 
Table 3. Annual cost of drip irrigation system used for the banana crop in Coimbatore district.

\begin{tabular}{llll}
\hline S.No. & Items & Cost (Rs/ha) & Percentage \\
\hline A & Annual fixed cost & & \\
1 & Annualized capital cost & 66,954 & 66.80 \\
2 & Depreciation on investment & 17,771 & 17.73 \\
3 & Interest & 8,035 & 8.02 \\
& Sub total & 92,760 & 92.55 \\
B & Annual operating and maintenance cost & & \\
1 & Repair and maintenance of drip & 6,911 & 6.90 \\
2 & Miscellaneous & 554 & 0.55 \\
& Sub total & 7465 & 7.45 \\
& Total cost (A+B) & $1,00,225$ & 100.00 \\
\hline
\end{tabular}

Table 4. Economics of banana cultivation in Coimbatore district of Tamil Nadu.

\begin{tabular}{lllll}
\hline SI. No. & Particulars & $\begin{array}{l}\text { Drip method of } \\
\text { irrigation }\end{array}$ & $\begin{array}{l}\text { Flood method of } \\
\text { irrigation }\end{array}$ & $\begin{array}{l}\text { Percentage change } \\
\text { over adoption }\end{array}$ \\
\hline 1 & Average yield (t/ha) & 21.35 & 20.05 & 6.48 \\
2 & Average price (Rs./Kg) & 28.25 & 28.25 & 0.00 \\
3 & Total returns (Rs./ha) & $6,03,137$ & $5,66,413$ & 6.48 \\
4 & Total cost (Rs./ha) & $2,58,249$ & $3,16,902$ & -18.51 \\
5 & Net returns (Rs./ha) & $3,44,888$ & $2,49,511$ & 38.23 \\
6 & Net Present Value (Rs/ha) & $43,851.16$ & $24,893.15$ & 76.16 \\
7 & Benefit Cost Ratio & 1.42 & 1.24 & 0.18 \\
\hline
\end{tabular}

Rs.2,58,249/ha while it was Rs.3,16,902/ha under the conventional method of irrigation. The total cost incurred in the cultivation of banana decreased by 18.51 per cent due to reduced labour usage for irrigation. The cost incurred was not reduced to a larger extent because of the higher cost of fertilizers used in fertigation system and the annual cost of the drip components installed.

The NPV criteria help to evaluate the benefits realized and cost incurred during the project life. The present value of net cash flows at 12.00 per cent discount rate was found to be Rs.43,851/ha. The positive net present value of drip irrigation on banana clearly indicates that investment on a drip irrigation system is financially feasible. The results of the study are analogous to studies by Narayanamoorthy et al. (2016) for green chillies in Tamil Nadu, Dave et al., (2016) for the banana in Gujarat, Chandrakanth et al. (2013) for vegetables and Patil et al. (2016) for grapes in Karnataka.

Another tool for appraising the worthiness of the investment is the Benefit Cost Ratio (BCR). It indicates the expected returns for each rupee of investment on drip irrigation. $\mathrm{BC}$ ratio for banana under drip irrigation was 1.42 while it was 1.24 in flood irrigation. Although investments on drip irrigation were high, the rewards were commensurate with investment required.

The selection norm for IRR is to accept the projects with IRR more than the opportunity cost of the capital. The IRR for the drip irrigation system on banana was found to be 30.88 per cent which was higher than the discount rate $(12.00 \%)$ used in the analysis. IRR indicates the average earning power of money invested on a drip irrigation system on a banana during its life span. The finding was in line with the study by Bakhsh et al. (2015) for wheat in Punjab and Patil et al. (2016) for grapes in Karnataka.

It was evident from table 4 that investment in $\mathrm{MI}$ technologies was highly remunerative. The results were similar to past studies, but the present study focused on small and marginal farmers having access to $100 \%$ subsidy but are forced to pay an additional amount for installing the components to their specification. Thus analyzing the economic viability on the investment made would create a positive view on MIS by farmers and helps in increasing its adoption rate. 
Kiruthika, S. and Kumar, D. S. / J. Appl. \& Nat. Sci. 12(3): 312 - 318 (2020)

Table 5: Constraints in adoption of MIS by small and marginal farmers of Coimbatore district.

\begin{tabular}{llll}
\hline SI.No & Particulars & Number of farmers & Percentage \\
\hline 1 & Non-availability of technical support & 66 & 94.28 \\
2 & High cost needed for investment & 57 & 81.43 \\
3 & Clogging of emitter/dripper & 50 & 71.43 \\
4 & Difficulty in cleaning laterals & 45 & 64.29 \\
5 & Easily damaged by animals & 33 & 47.14 \\
6 & Small size of landholding & 03 & 4.29 \\
7 & Technology is irrelevant/inferior & 02 & 2.86 \\
\hline
\end{tabular}

The higher NPV, BCR and IRR indicates that the investment on drip irrigation is worthy for banana cultivation.

Constraints faced by farmers in the adoption of drip irrigation: Studying the constraints or problems related to the adoption of MIS is essential as it is an innovative technology promoted highly by the government by means of subsidy. It will be helpful in further modification of technology and reforms of the policy. The major constraints reported by farmers are listed in table 5 .

About 94.28 per cent of farmers expressed a lack of technical support and follow-up action from MIS companies as the major constraint. It takes years of experience for the farmers to identify the problems in the operation of components which can be prevented by conducting demonstrations and providing timely service by the companies. The next major constraint was the higher investment required for which the state government of Tamil Nadu provides 100\% subsidy. But it is not convenient for the farmers as they have to pay an additional amount to get site-specific components based on their cropping pattern.

Clogging of the emitter was also an important problem faced by farmers which is caused due to the use of saltwater. The laterals were easily damaged by animals like peacock, squirrel and boar. The problem in cleaning the laterals and emitters were also reported. Technology is considered irrelevant only by few farmers as the groundwater quality in their area was poor.

\section{Conclusion}

Finding out the financial viability of using MI technologies and other significant impacts on farmers livelihood of Coimbatore district would give a clear understanding of the importance of using the technology. The study is useful to know the true role of a $100 \%$ subsidy given for MIS adoption to small and marginal farmers and will be helpful in further policy reforms. The results of the study have convincingly shown that investment on drip irrigation systems for banana was economically viable with higher net present worth, benefit-cost ratio and internal rate of return over the conventional

method of irrigation. A significant impact of using MIS on cropping pattern, gross cropped area, expansion in area under irrigation and area irrigated by different sources were found. Most of the farmers used MIS for wider spaced horticultural crops like areca nut, coconut, banana, turmeric rather than agricultural crops like cereals, pulses and cotton which showed that predetermined cropping pattern of farmers forbids them to use the technology. The problems faced by adopters of MIS were found to be lack of technical support, high cost of investment, clogging of emitters and damage by wild animals. Farmers in the study area also reported the inconvenience in the specifications of components of a drip irrigation system provided under $100 \%$ subsidy. They were unable to pay an extra amount to get site-specific components which lead to a decreased rate of adoption of the technology. The farmers were well aware of the financial feasibility of the system but restricted from adopting the technology due to the high investment required. As the economic viability of MIS was proven, steps must be taken to disburse subsidy as desired by farmers and change the components specification.

\section{REFERENCES}

1. Bakhsh, A., Ashfaq, M., Ali, A., Hussain, M., Rasool, G., Haider, Z., \& Faraz, R. H. (2015). Economic evaluation of different irrigation systems for wheat production in Rechna Doab, Pakistan. Pak. J. Agri. Sci, 52(3), 821-828.

2. Chandrakanth, M. G., Priyanka, C. N., Mamatha, P., \& Patil, K. K. (2013). Economic benefits from micro irrigation for dry land crops in Karnataka. Indian Journal of Agricultural Economics, 68(902-2016-66842), 326-338. DOI: 10.22004/ag.econ.206338

3. Dave, A.K., Y.C. Zala and R.S. Pundir (2016), "Comparative Economics of Banana Cultivation in Anand District of Gujarat", Economic Affairs, Vol. 61, No. 2, pp. 305-312. DOI:10.5958/0976-4666.2016.00039.5

4. Dhawan, B.D. 2000. Drip irrigation: Evaluating returns. Economic and Political Weekly, 3775-3780. 
5. Government of India. (2018). Agricultural statistics at a glance, Directorate of Economics and Statistics. Dept. of Agric. and Co-operation. Ministry of Agriculture.

6. Government of India (2019). Ground Water Year Book India 2017-2018, Central Ground Water Board, Ministry of Water Resources, Faridabad.

7. INCID (1994), Drip Irrigation in India, Indian National Committee on Irrigation and Drainage, New Delhi.

8. IAI, FICCI and GTI (2016). Irrigation Association of India (IAI) and Federation of Indian Chambers of Commerce and Industry ( $\mathrm{FICCl})$; and Grant Thornton India (GTI)Accelerating growth of Indian Agriculture: Micro irrigation an efficient solution, Strategy paper - Future prospects of Indian Agriculture, Ministry of Agriculture and Farmers Welfare, Government of India.

9. Kishore, P. (2019). Efficiency gains from micro-irrigation: a case of sprinkler irrigation in wheat. Agricultural Economics Research Review, 32(2), 239-246. DOI : 10.5958/09 74-0279.2019.00035.1

10.Kumar, D. S., \& Palanisami, K. (2014). Impact of drip irrigation on farming system: evidence from southern India. Management, Performance, and Applications of Micro Irrigation Systems, 19.

11.Kumar, M. D. (2016). Water saving and yield enhancing micro irrigation technologies in India: Theory and practice. In Micro irrigation systems in India (pp. 13-36). Springer, Singapore. DOI : https://doi.org/10.1007/978-981-100348-6_2

12.Kumar, M. Dinesh., K. Singh, O.P. Singh, and R.L. Shiyani. 2004. Impacts of water saving and energy saving irrigation technologies in Gujarat, Research Report 2, India Natural Resources Economics and Management Foundation, Anand.

13.Luhach, M. S., Khatkar, R. K., Singh, V. K., \& Khatry, R. S. (2004). Economic analysis of sprinkler and drip irrigation technology in Haryana. Agricultural Economics Research Review, 17(347-2017-3183), 107-113. DOI :10.220 04/ag.econ. 265893

14.Narayanamoorthy, A. (1996), Evaluation of Drip Irrigation System in Maharashtra, Mimeograph Series No. 42, Agro-
Economic Research Centre, Gokhale Institute of Politics and Economics, Pune, Maharashtra.

15.Narayanamoorthy, A., N. Devika and M. Bhattarai, (2016), "More Crop and Profit Per Drop of Water: Drip Irrigation for Empowering Distressed Small Farmers", Kozhikode Society and Management Review, Vol. 5, No.1, PP. 8390. https://doi.org/10.1177/2277975215617270

16.Palanichamy N.V., K. Palanisamy and T.R. Shanmugam (2002), Economic performance of drip irrigation in coconut farmers in Coimbatore. Agricultural Economics Research Review, Conference Issue, pp. 40-48.

17.Patil, B. O., \& Poddar, R. S. (2016). Financial feasibility of drip irrigation system in grape cultivation. International Journal of Agriculture, Environment and Biotechnology, 9 (4), 617-624. DOI : 10.5958/2230-732X.2016.00080.2

18.Paul, J. C., Mishra, J. N., Pradhan, P. L., \& Panigrahi, B. (2013). Effect of drip and surface irrigation on yield, wateruse-efficiency and economics of capsicum (c apsicum annum I.) Grown under mulch and non mulch conditions in eastern coastal India. European Journal of Sustainable Development, 2(1), 99-99. DOI: https://doi.org/10.14207/ ejsd.2013.v2n1p99

19.Shashidhara, K.K.; A. Bheemappa, L.V. Hirevenkanagoudar and K.C. Shashidhar (2007), "Benefits and Constraints in Adoption of Drip Irrigation Among the Plantation Crop Growers", Karnataka Journal of Agricultural Sciences, Vol.20, No.1, pp. 82-84.

20.Shiyani R.L., D. B. Kuchhadiya and M.V. Patat (1999), Economic impact of drip irrigation technology on cotton growers of Saurashtra region. Agricultural Situation in India, 56 (7): 407-412.

21.Singh, A. (2008). Economic feasibility of growing capsicum crop under drip irrigation in West Bengal, India. Irrigation and Drainage Systems, 22(2), 179-188. https://doi.org/10.1007/s10795-008-9050-x

22.Sivanappan, R. K. (1994). Prospects of micro-irrigation in India. Irrigation and drainage systems, 8(1), 49-58. DOI : https://doi.org/10.1007/BF00880798

23.Vaibhav, R., \& Makwana, A. D. (2017). Case study: Impact analysis of Micro Irrigation System in Kodinar Region of Gujarat. Trends in Biosciences, 10(48):9609-9612. 